\title{
Methods for Protecting Network from Islanding Danger
}

Yasser Ahmed Elshrief ${ }^{1}$, A D Asham ${ }^{1}$, Belal Ahmed Abozalam², and Sameh Abd-Elhaleem²

${ }^{1}$ Electrical Department, Egyptian Academy for Engineering and Advanced Technology

${ }^{2}$ Industrial Electronics and Control Engineering Department, Menofia University

January 25, 2021

\section{Hosted file}

Methods for protecting Network from Islanding Danger.pdf available at https://authorea.com/ users/391588/articles/505643-methods-for-protecting-network-from-islanding-danger 